\title{
Histone deacetylase inhibitor KBH-A42 inhibits cytokine production in RAW 264.7 macrophage cells and in vivo endotoxemia model
}

\author{
Yongseok Choi ${ }^{1 *}$, Song-Kyu Park ${ }^{2 *}$, \\ Hwan Mook Kim ${ }^{2,6}$, Jong Soon Kang ${ }^{2}$, \\ Yeo Dae Yoon ${ }^{2}$, Sang Bae Han ${ }^{3}$, Jeung Whan $\mathrm{Han}^{4}$, \\ Jee Sun Yang ${ }^{5}$ and Gyoonhee Han $^{5,6}$ \\ ${ }^{1}$ School of Life Sciences and Biotechnology \\ Korea University \\ Seoul 136-701, Korea \\ ${ }^{2}$ Bio-evaluation Center \\ Korea Research Institute of Bioscience and Biotechnology (KRIBB) \\ Chungbuk 363-883, Korea \\ ${ }^{3}$ College of Pharmacy \\ Chungbuk National University \\ Cheongju 361-763, Korea \\ ${ }^{4}$ College of Pharmacy \\ Sungkyunkwan University \\ Suwon 440-746, Korea \\ ${ }^{5}$ Department of Biotechnology \\ Yonsei University \\ Seoul 120-740, Korea \\ ${ }^{6}$ Corresponding authors: Tel, 82-43-240-6500; Fax, 82-43-240-6529; \\ E-mail, hwanmook@kribb.re.kr (H. Kim) and \\ Tel, 82-2-2123-2882; Fax, 82-2-362-7265; \\ E-mail, gyoonhee@yonsei.ac.kr (G. Han) \\ *These authors contributed equally to this work. \\ DOI 10.3858/emm.2008.40.5.574
}

Accepted 1 July 2008

Abbreviations: HDAC, histone deacetylase; HDLP, histone deacetylase like protein; SAHA, suberoylanilide hydroxamic acid; TSA, trichostatin $A$

\footnotetext{
Abstract

In light of the anti-inflammatory properties of histone deacetylase (HDAC) inhibitors, such as suberoylanilide hydroxamic acid (SAHA) and trichostatin A (TSA), we examined a new HDAC inhibitor KBH-A42 for its anti-inflammatory activities. KBH-A42 showed noteworthy anti-inflammatory properties in vitro via suppression of the production of TNF- $\alpha$, a proinflammatory cytokine, and nitric oxide (NO), a proinflammatory effector molecule, in LPS-stimulated RAW264.7 cells and peritoneal macrophages. It also inhibited TNF- $\alpha$ production in vivo as demonstrated in
}

a LPS-induced mouse endotoxemia model. The levels of TNF- $\alpha$, IL-1 $\beta$, IL- 6 and iNOS mRNAs determined by RT-PCR propose that the inhibition of these pro-inflammatory mediators by KBH-A42 resulted from inhibiting expression of these genes. However, the EMSA study to see the effect of KBH-A42 on the binding of NF- $\mathrm{KB}$, a transcription factor, to a specific DNA sequence showed that the binding of NF-KB to DNA was not changed regardless of increasing the concentration of KBH-A42 in the presence and absence of LPS stimulation. Interestingly, DNA binding of another transcription factor AP-1 dose-dependently increased by KBH-A42. KBH-A42 differentially regulated the phosphorylation of MAP kinases. While the phosphprylation of ERK1/2 and SAPK/JNK was not affected by KBH-A42, the phosphorylation of p38 decreased by KBH-A42. These results showed that KBH-A42 inhibits production of proinflammatory cytokines in macrophages by decreasing their mRNA levels, and p38 kinase is involved in the KBH-A42-mediated inhibition.

Keywords: anti-inflammatory agents; histone deacetylases; NF- $\mathrm{KB}$; nitric oxide; transcription factor AP-1; tumor necrosis factor- $\alpha$; vorinostat

\section{Introduction}

Histone decetylase (HDAC) and histone acetyltransferase (HAT) have important roles in chromatin remodeling and "epigenetic control" of gene expression (Wu et al., 2000). HDAC catalyzes deacetylation of $\varepsilon$-amino group in lysines located near the N-terminal of core histone proteins. Deacetylation associates to transcriptional repression and abnormal recruitment of HDAC is related to carcinogenesis (Archer et al., 1999; Kouzarides et al., 1999). Studies have shown that inhibition of HDAC elicits anticancer effects in several tumor cells by inhibition of cell growth. This has led to the development of HDAC inhibitors for anti-cancer chemotherapy (Johnstone et al., 2002). Moreover, epigenetic control of chromatin involves various major cell functions such as cell growth, differentiation, and apoptosis (Jaenisch et al., 2003). It has been recently revealed that HDAC inhibitors have antiinflammatory activities via suppression of cyto- 
kines and nitric oxide (NO) (Blanchard et al., 2005). Butyrate reduced $\mathrm{IL}-12$ transcription in T-cells (Diakos et al., 2002) and human blood monocytes (Saemann et al., 2000), and inhibited NO production in RAW macrophage cells (Chakravortty et al., 2000). Suberoylanilide hydroxamic acid (SAHA) inhibited secretion of TNF- $\alpha$, IL-1 $\beta$, IL-6, and IFN- $\gamma$ in LPS-induced PBMC cells, and also inhibited their in vivo production as shown in an LPS induced animal model (Leoni et al., 2002). Appropriate control of TNF- $\alpha$ has been considered as a potential approach for the treatment of rheumatoid arthritis (RA) (Newton et al., 1999; Palladino et al., 2003) along with the success of anti-TNF- $\alpha$ biologics (Moreland et al., 1997; Lipsky et al., 2000). Several "the next generation" antiTNF- $\alpha$ small molecule approaches have been in progress because of the significant advantage of developing orally active molecules in low cost (Palladino et al., 2003). HDAC inhibitor, Trichostatin A (TSA) caused the apoptosis of osteoclast by up regulating $\mathrm{p} 21^{\mathrm{WAF} 1}$ and is a possible therapeutic agent for osteoporosis (Yi et al., 2007). These results suggest that HDAC could be a potential target for many other non-malignant diseases such as rheumatoid arthritis and osteoporosis.

Recently, we have reported preparation of a novel series of HDAC inhibitors and evaluation of their anti-proliferative and anti-inflammatory activities (Kim et al., 2006, 2007). As a part of our ongoing optimization process of our HDAC inhibitors, we were interested in investigating of $\mathrm{KBH}-\mathrm{A} 42$ for its anti-inflammatory activity since it was screened from a cell based TNF- $\alpha$ inhibition assay. With its unique HDAC inhibitory activity pattern, $\mathrm{KBH}-\mathrm{A} 42$ was subjected to the cellular cytokine inhibition, molecular mechanism, and in vivo TNF- $\alpha$ inhibition studies.

\section{Materials and Methods}

\section{Compounds}

KBH-A42 (Kim et al., 2006) and suberoylanilide hydroxamic acid (SAHA) (Gediya et al., 2005) were prepared by the reported procedures.

\section{HDAC assay}

HDAC fluorescent activity assays using a Fluror de Lys substrate (Biomol, Plymouth Meeting, PA), which contains an acetylated lysine side chain, were performed according to manufacturer's instructions. In brief, HeLa nuclear extracts, which were used as an HDAC enzyme source, were incubated at $25^{\circ} \mathrm{C}$ with $250 \mathrm{mM}$ of Fluror de Lys substrate and various concentrations of $\mathrm{KBH}-\mathrm{A} 42$ and SAHA. Reactions were stopped after 20 min with Fluror de Lys developer and fluorescence was measured using a microplate spectrofluorometer (LS 50B, Perkin Elmer) with excitation at $360 \mathrm{~nm}$ and emission at $460 \mathrm{~nm}$.

\section{Immunoblotting of p21 ${ }^{\text {WAF1 }}$ and acetylated histone $\mathrm{H} 4$}

HeLa cells were incubated with apicidin $(1 \mu \mathrm{M})$, $\mathrm{KBH}-\mathrm{A} 42(10 \mu \mathrm{M})$ or $0.1 \%$ DMSO in culture medium for $24 \mathrm{~h}$. Cell lysates were boiled in Laemmli sample buffer for $3 \mathrm{~min}$, and $30 \mu \mathrm{g}$ of each total protein were subjected to SDS-PAGE on $15 \%$ slab gels for the analysis of $\mathrm{p} 21^{\text {WAF } 1 / \text { Cip } 1}$ and acetylated histone H4. Proteins were transferred to PVDF membranes, and membranes were blocked for 30 min in PBS containing $0.1 \%$ Tween 20 (PBS-T) and $5 \%(\mathrm{w} / \mathrm{v})$ skim milk, and incubated overnight with anti- p21 WAF1/Cip1 (Santa Cruz Biotechnologies, Inc) and acetylated histone $\mathrm{H} 4$ (Upstate Biotechnology) antisera. The membranes were then washed with PBS-T and incubated for $2 \mathrm{~h}$ with an secondary antibody. Bound antibodies were detected with the enhanced amplified alkaline phosphatase immunoblot system (Bio-Rad).

\section{In vitro NO assay and TNF- $\alpha$ inhibition assay}

LPS (200 ng/ml)-stimulated RAW264.7 cells were cultured with $\mathrm{KBH}-\mathrm{A} 42$ or SAHA for $24 \mathrm{~h}$. $\mathrm{NO}_{2}{ }^{-}$ accumulation was used as an indicator of NO production in the medium. The isolated supernatants were mixed with an equal volume of Griess reagent ( $1 \%$ sulfanilamide, $0.1 \%$ naphthylethylenediamine dihydrochloride, and $2 \%$ phosphoric acid) and incubated at room temperature for 10 min. Nitrite production was determined by measuring absorbance at $540 \mathrm{~nm}$ versus a $\mathrm{NaNO}_{2}$ standard curve. The concentration of TNF- $\alpha$ secreted in the culture supernatant of RAW264.7 cells was determined by ELISA, according to the manufacture's instruction (R\&D Systems, Minneapolis, $\mathrm{MN})$.

\section{Determining cell viability by propidium iodide (PI) staining}

LPS (200 ng/ml)-stimulated RAW 264.7 cells were cultured in the presence of various concentrations of $\mathrm{KBH}-\mathrm{A} 42$ for $24 \mathrm{~h}$. Cells were collected, washed twice in PBS containing $0.1 \% \mathrm{BSA}$, and resuspended in $500 \mu$ of PBS containing PI $5 \mu \mathrm{g} / \mathrm{ml}$ for $10 \mathrm{~min}$. Cells were analyzed using an FACSCalibur flow cytometer (BD Biosciences, San Jose, CA), and data were analyzed using WinMidi software 
(Scripps, LaHoya, CA).

\section{In vivo TNF- $\alpha$ inhibition assay}

The compounds were administered intraperitoneally or orally to mice $24 \mathrm{~h}$ and $2 \mathrm{~h}$ before LPS injection. LPS $(20 \mu \mathrm{g})$ was injected intraperitoneally to boost the concentration of TNF- $\alpha$ in the blood. Plasma was prepared $30,60,90$ and 120 min after LPS treatment and the TNF- $\alpha$ level was measured by ELISA, according to the manufacture's instruction (R\&D Systems, Minneapolis, MN).

\section{Measurement of mRNA expression by RT-PCR}

The expression of cytokines was measured by RT-PCR. The cells were treated with KBH-A42 $1 \mathrm{~h}$ before LPS stimulation and total RNA was isolated $6 \mathrm{~h}$ after LPS stimulation $(200 \mathrm{ng} / \mathrm{ml})$. The RNA was reverse transcribed using a GeneAmp RNA PCR kit using $100 \mathrm{ng}$ of total cellular RNA (PerkinElmer). PCR was carried out using $2.5 \mathrm{U}$ of AmpliTaq DNA polymerase in a Bio-Rad Cycler (Bio-Rad Lab). PCR products were electrophoresed on a $3 \%$ Nusieve 3:1 agarose gel and photographed after staining with ethidium bromide.

\section{Electrophoretic mobility shift assay (EMSA)}

The protein content of the nuclear extracts of RAW 264.7 cells was determined using a Bio-Rad protein assay kit according to the manufacturer's instruction (Bio-Rad, Hercules, CA). The oligonucleotide sequence for NF-kB/Rel and AP-1 was 5'-GATCTCAGAGGGGACTTTCCGAGAGA-3' and 5'-GATCTGCATGAGTCAGACACA-3'. Double-stranded oligonucleotides were end-labeled with $\left[\gamma_{-}{ }^{32}\right.$ P]ATP. Nuclear extracts $(5 \mu \mathrm{g})$ were incubated with $2 \mu \mathrm{g}$ of poly (dl-dC) and a ${ }^{32} \mathrm{P}$-labeled DNA probe in binding buffer $(100 \mathrm{mM} \mathrm{KCl}, 30 \mathrm{mM}$ HEPES, $1.5 \mathrm{mM}$ $\mathrm{MgCl}_{2}, 0.3 \mathrm{mM}$ EDTA, $10 \%$ glycerol, $1 \mathrm{mM}$ DTT, 1 $\mathrm{mM}$ PMSF, $1 \mu \mathrm{g} / \mathrm{ml}$ of aprotinin and $1 \mu \mathrm{g} / \mathrm{ml}$ of leupeptin) for $10 \mathrm{~min}$. DNA binding activity was separated from the free probe using a $4.8 \%$ polyacrylamide gel in $0.5 \times$ TBE buffer $(44.5 \mathrm{mM}$ Tris, $44.5 \mathrm{mM}$ boric acid and $1 \mathrm{mM}$ EDTA). Following electrophoresis, the gel was dried and subjected to autoradiography.

\section{Western immunoblot analysis}

Whole cell lysates $(20 \mu \mathrm{g}$, for phospho-ERK1/2, phospho-SAPK/JNK, phospho p38, and p38) were separated by $10 \%$ SDS-PAGE, then electro-transferred to nitrocellulose membranes (Amersham International, Buckinghamshire, UK). The membranes were preincubated for $1 \mathrm{~h}$ at room temperature in Tris-buffered saline (TBS), pH 7.6, containing $0.05 \%$ Tween 20 and $3 \%$ BSA. The nitrocellulose membranes were incubated with phosphorylated ERK1/2, phosphorylated SAPK/JNK, phosphorylated p38 or p38-specific antibodies. Immunoreactive bands were then detected by incubation with conjugates of anti-rabbit IgG with HRP and enhanced chemiluminescence reagents (Amersham).

\section{Molecular modeling}

The program Insight II was used to create a docking model for HDAC-1 based on the crystal structure of HDLP. Both proteins are class 1 HDAC's and share $32 \%$ identity. Key residues which are conserved include Asp-168, His-170, and Asp-258, which chelate the $\mathrm{Zn}^{2+}$, and His-131, His-132, and Tyr-297, which interact with the hydroxamic acid (HDLP numbering). His -131 and -132 form charge relays with Asp-166 and Asp-173, respectively, and these residues are also conserved. A narrow channel in the binding pocket is formed by Phe-141 and Phe-198, residues which are also conserved in HDAC-1. At the top of the binding pocket, Glu-92 in HDLP is mutated to Asp in HDAC-1 and Tyr-91 is mutated to Glu. Docking calculations for $\mathrm{KBH}-\mathrm{A} 42$ were carried out with the program Discover (McMartin et al., 1997). The hydroxamic acid moiety was constrained to the conformation seen in the crystal structure, while the rest of the inhibitor was free to move. Mutated residues were allowed to relax during the minimization steps.

\section{Results}

\section{In vitro assays}

The preliminary evaluation of a HDAC inhibitor $\mathrm{KBH}-\mathrm{A} 42$ on inhibition of TNF- $\alpha$ and NO in RAW 264.7 cells was in our previous communication (Kim et al., 2007). SAHA, a known HDAC inhibitor, was

Table 1. In vitro inhibition of HDAC enzyme and the inhibition of TNF- $\alpha$ and NO by KBH-A42 and SAHA.

\begin{tabular}{lccc}
\hline \multirow{2}{*}{ Compound } & \multicolumn{3}{c}{$\mathrm{IC}_{50}(\mu \mathrm{M})^{\mathrm{a}}$} \\
\cline { 2 - 4 } & $\mathrm{HDAC}^{\mathrm{b}}$ & $\mathrm{TNF}-\alpha^{\mathrm{c}}$ & $\mathrm{NO}^{\mathrm{c}}$ \\
\hline KBH-A42 & $0.27 \pm 0.10$ & $1.10 \pm 2.14$ & $2.71 \pm 3.02$ \\
SAHA & $0.11 \pm 0.02$ & $1.55 \pm 1.44$ & $0.51 \pm 0.67$ \\
\hline
\end{tabular}

${ }^{a}$ Values are the means of a minimum of three experiments. ${ }^{b} \mathrm{HDAC}$ enzyme obtained from HeLa cell lysate. 'RAW264.7 cells were used. 
used as a reference compound. $\mathrm{KBH}-\mathrm{A} 42$ showed a good inhibitory activity to the partially purified HDAC enzyme, obtained from HeLa cell lysates, and its $\mathrm{IC}_{50}$ value was $0.27 \mu \mathrm{M}$. Inhibition of TNF- $\alpha$ and $\mathrm{NO}$ production were performed in the LPS induced murine macrophage RAW 264.7 cells. $I_{50}$ values of $\mathrm{KBH}-\mathrm{A} 42$ against TNF- $\alpha$ and $\mathrm{NO}$ production were 1.10 and $2.71 \mu \mathrm{M}$, respectively, which were comparable to those of SAHA (Table $1)$. Nitric oxide inhibition assay in peritoneal macrophage cells showed that KBH-A42 inhibited $38 \%$ of NO production at $0.1 \mu \mathrm{M}$ (Table 2). Further reduction was observed; $60 \%$ and $93 \%$ at 0.3 and $1 \mu \mathrm{M}$, respectively. $\mathrm{KBH}-\mathrm{A} 42$ also showed typical characteristics of HDAC inhibitors, such as increasing the hyperacetylation level of histone $4(\mathrm{H} 4)$ and the expression of cyclin-dependent kinase inhibitor p21 ${ }^{\text {WAF1 }}$ (Figure 2) (Archer et al., 1998).

\section{$K B H-A 42$ inhibits production of TNF- $\alpha$ in in vivo model}

TNF- $\alpha$ inhibitory effect of $K B H-A 42$ was then examined in vivo (Table 3 ) with an insight of promising results of TNF- $\alpha$ and NO inhibition. In this model, $K B H-A 42$ was administered (i.p or p.o) to mice 24 $\mathrm{h}$ and $2 \mathrm{~h}$ before intraperitoneal injection of LPS for the purpose of inducing TNF- $\alpha$ production in mice. $K B H-A 42$ inhibited TNF- $\alpha$ production in a dose dependent manner and showed $50 \%$ inhibition at the tested dose of $10 \mathrm{mg} / \mathrm{kg}$ (i.p.), compared to the TNF- $\alpha$ level in mice receiving LPS stimulation alone. In the case of p.o. administration, the

Table 2. In vitro inhibition of NO by KBH-A42 in mouse peritoneal macrophage cells and RAW 264.7 cells.

\begin{tabular}{|c|c|c|c|c|c|}
\hline \multirow[b]{2}{*}{$K B H-A 42$} & \multicolumn{3}{|c|}{$\begin{array}{l}\text { Mouse peritoneal } \\
\text { macrophage cells }\end{array}$} & \multicolumn{2}{|c|}{ RAW 264.7 cells } \\
\hline & $\begin{array}{c}\mathrm{NO} \\
\left(\mathrm{nmol} / 10^{6}\right. \\
\times \text { cells })\end{array}$ & $\begin{array}{l}\text { Inhibition } \\
\qquad(\%)^{\mathrm{b}}\end{array}$ & $\begin{array}{c}\text { Cytoto- } \\
\text { xicity } \\
(\%)^{\mathrm{C}}\end{array}$ & $\begin{array}{c}\mathrm{NO} \\
\left(\mathrm{nmol} / 10^{6}\right. \\
\times \text { cells })\end{array}$ & $\begin{array}{c}\text { Inhibition } \\
(\%)^{\mathrm{b}}\end{array}$ \\
\hline Saline & -1 & NA & 35 & 1 & - \\
\hline Veh + LPS & $41 \pm 2$ & 0 & 34 & $40 \pm 2$ & - \\
\hline 0.01 & $30 \pm 1$ & 28.6 & 33 & - & - \\
\hline 0.03 & $29 \pm 1$ & 31.0 & 35 & - & - \\
\hline 0.1 & $26 \pm 2$ & 38.1 & 34 & - & - \\
\hline 0.3 & $17 \pm 2$ & 59.5 & 32 & $44 \pm 2$ & 0 \\
\hline 1 & $3 \pm 2$ & 92.9 & 32 & $36 \pm 2$ & 10 \\
\hline 3 & $-1 \pm 1$ & 100 & 30 & $14 \pm 2$ & 65 \\
\hline 10 & -1 & 100 & 59 & $6 \pm 1$ & 85 \\
\hline
\end{tabular}

${ }^{a}$ Values are the means of five experiments. ${ }^{b}$ Mouse peritoneal macrophage cells were used. 'Cytotoxicity was measured by PI staining method. production of TNF- $\alpha$ was also inhibited dosedependently and displayed more than $50 \%$ inhibition at the tested dose of $30 \mathrm{mg} / \mathrm{kg}$. However, no further increase in inhibition was observed at<smiles>CCCC(=O)O</smiles>

Butyric acid (1)<smiles>O=C(CCCCCCC(=O)Nc1ccccc1)NO</smiles>

SAHA (2)<smiles>O=C(CCC1=CCCN(CCCc2ccccc2)C1=O)NO</smiles>

KBH-A42 (3)

Figure 1. Structures of HDAC inhibitors.

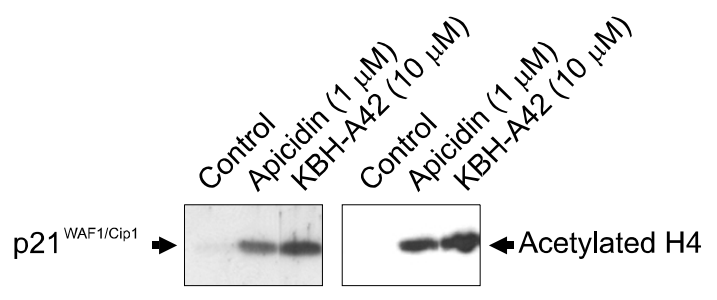

Figure 2. Induction of $\mathrm{p} 21^{\text {WAF1 }}$ expression and histone $\mathrm{H} 4$ hyperacetylation by apicidin and KBH-A42. Lysates $(30 \mu \mathrm{g})$ of the HeLa cells exposed to $1 \mu \mathrm{M}$ apicidin, or $10 \mu \mathrm{M}$ KBH-A42 (Lanes 2-3 respectively) or $0.1 \%$ DMSO (Lane 1 ) were examined by $15 \%$ SDS-PAGE and analyzed with immunoblotting using antibodies for $\mathrm{p} 21^{\text {WAF } 1 / \text { Cip } 1}$ and acetylated histone $\mathrm{H} 4$.

Table 3. In vivo inhibition of LPS induced TNF- $\alpha$ by KBH-A42.

\begin{tabular}{|c|c|c|c|c|c|c|}
\hline \multirow{2}{*}{ Compound } & \multirow{2}{*}{$\begin{array}{l}\text { Dose } \\
(\mathrm{mg} / \mathrm{kg})\end{array}$} & \multicolumn{3}{|c|}{ i.p. $^{a}$} & \multicolumn{2}{|c|}{ p.o. $^{a}$} \\
\hline & & 1 & 3 & 10 & 10 & 30 \\
\hline KBH-A42 & $\begin{array}{l}\text { Inhibition } \\
(\%)\end{array}$ & 25.3 & $27.6^{\star}$ & $49.1^{*}$ & $31.2^{\star \star}$ & $53.6^{*}$ \\
\hline
\end{tabular}

${ }^{\mathrm{a} B A L B / c}$ mice (four per group) were treated. KBH-A42 was pretreated twice (i.p. or p.o.) at $24 \mathrm{~h}$ and $2 \mathrm{~h}$ before LPS (1.5 mg/kg, i.p.) was injected. Serum TNF- $\alpha$ was measured after 60 min. ${ }^{*} P<0.05$; ${ }^{* *} P<$ 0.01 . 
A

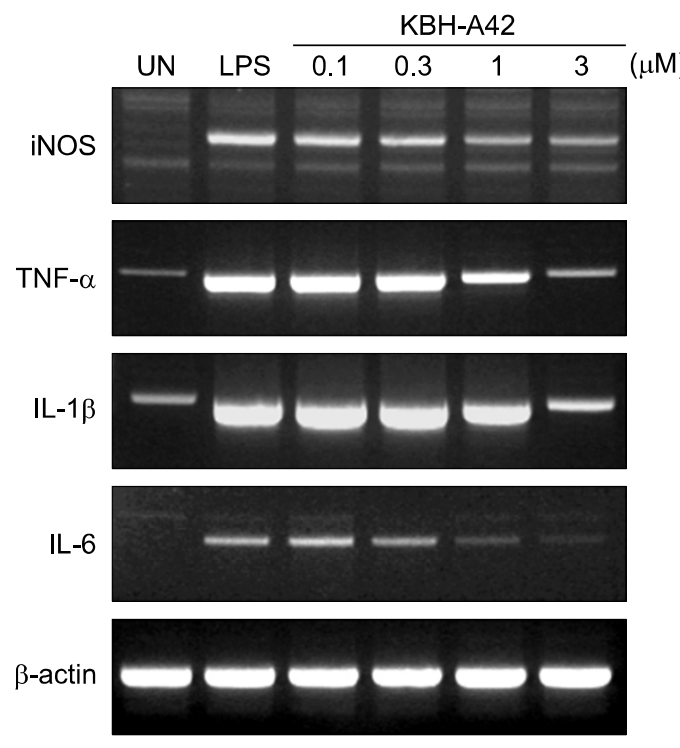

B
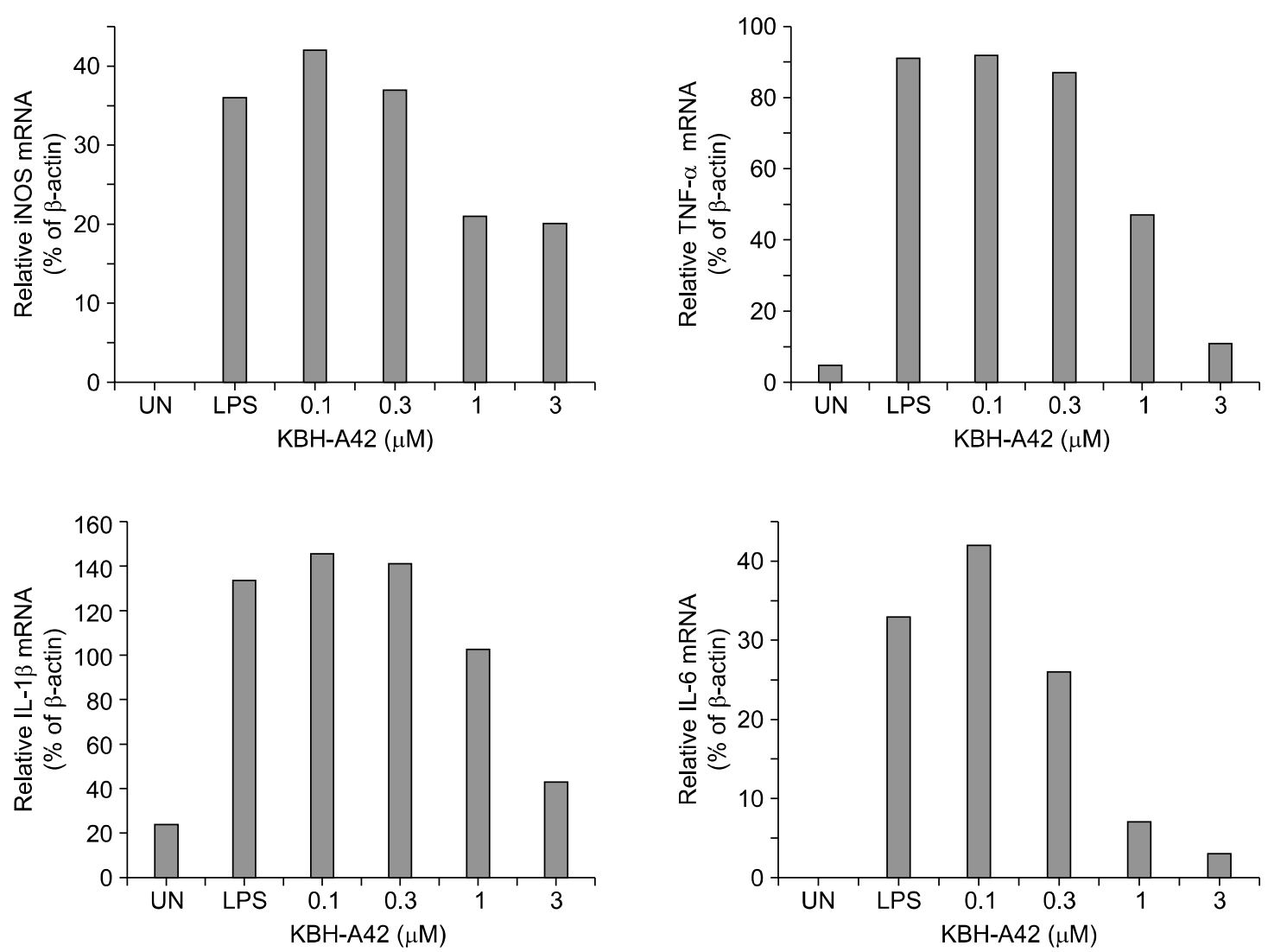

Figure 3. (A) mRNA levels of iNOS, TNF- $\alpha$, IL-1 $\beta$ and IL- 6 by RT-PCR (RAW 264.7 macrophage cells). HDAC inhibitor, KBH-A42 was treated $1 \mathrm{~h}$ before LPS stimulation. Total RNA's of RAW 264.7 cells were isolated $6 \mathrm{~h}$ after LPS stimulation ( $200 \mathrm{ng} / \mathrm{ml})$ and RT-PCR was performed on iNOS, TNF- $\alpha$, IL-1 $\beta$, IL- 6 and $\beta$-actin mRNA's. (B) Densitometric analysis of autoradiographic signals corresponding to iNOS, THF- $\alpha$, IL-1 $\beta$, IL-6 mRNAs corrected on the basis of $\beta$-actin mRNA signals in the same lane. 


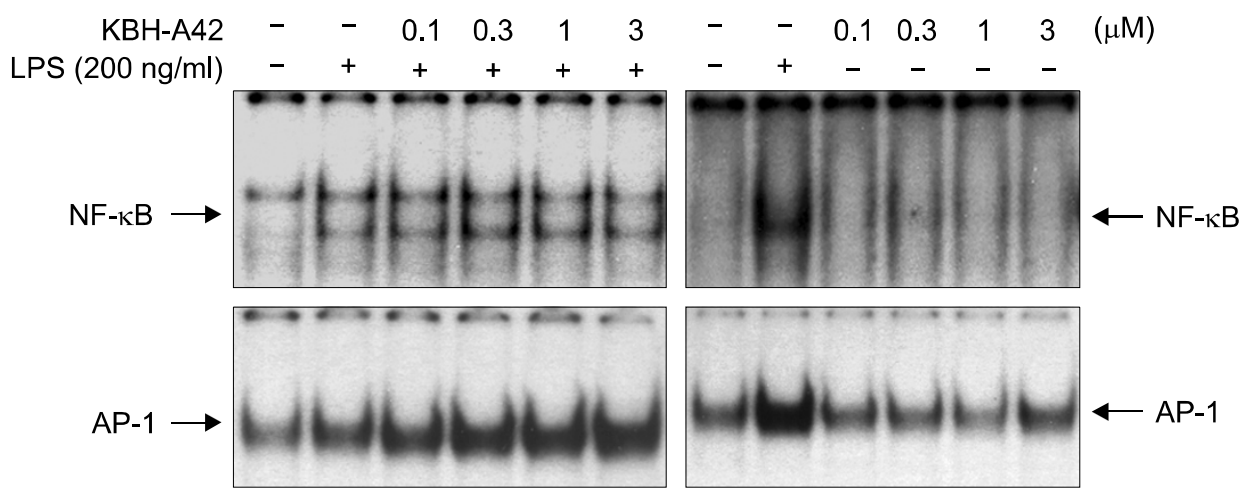

Figure 4. EMSA (RAW 264.7 cells, $5 \times 10^{5} \mathrm{cell} / \mathrm{ml}$ ) for NF-KB and AP-1 at $1 \mathrm{~h}$ after LPS stimulation (200 ng/ml). HDAC inhibitor, KBH-A42 was treated $1 \mathrm{~h}$ before LPS stimulation.

the higher dose level of $100 \mathrm{mg} / \mathrm{kg}$.

\section{Mechanism study}

Along with in vitro and in vivo results, $\mathrm{KBH}-\mathrm{A} 42$ showed inhibitory activities against TNF- $\alpha$ and NO production in RAW 264.7 cells. Thus, mRNA levels of iNOS, TNF- $\alpha$, IL-1 $\beta$, and IL- 6 in LPS induced RAW 264.7 cells were evaluated by RT-PCR (Figure 3). KBH-A42 was treated $1 \mathrm{~h}$ before LPS and total RNAs of RAW 264.7 cells were isolated 6 $\mathrm{h}$ after LPS. All mRNA levels of iNOS, TNF- $\alpha$, IL-1 $\beta$, and IL- 6 decreased in a dose dependent manner by KBH-A42 compared to those with LPS stimulated cells. These results indicate that KBH-A42 exerts its inhibitory activities on inflammatory cytokine production at mRNA expression level. To see if the inhibition of the mRNAs by $\mathrm{KBH}-\mathrm{A} 42$ was due to inhibition of the activity of transcription factors, the possibility that $\mathrm{KBH}-\mathrm{A} 42$ affects transcription factors, such as NF-kB, was investigated. NF- $\mathrm{KB}$ has a very important role in expression of pro-inflammatory mediators such as iNOS, interleukins, and TNF- $\alpha$. Many anti-inflammatory drugs are known to target to inhibit an activation of this transcription factor. (D'Acuisto et al., 2002; Kyung et al., 2008) However, the effects on activity of transcription factors by $\mathrm{KBH}-\mathrm{A} 42$ are quite mixed-up in RAW 264.7 cells (Figure 4). The effect of KBH-A42 on transcription factors was determined by measuring the extent of DNA binding of transcription factors. $\mathrm{KBH}-\mathrm{A} 42$ was treated in the presence and absence of LPS. When cells were treated with LPS, KBH-A42 was treated $1 \mathrm{~h}$ before LPS stimulation. The extent of DNA binding of NF- $\kappa B$ and AP-1 was examined $1 \mathrm{~h}$ after LPS stimulation using the EMSA method. The DNA binding activity of NF-KB was not changed with increasing the concentration of $\mathrm{KBH}-\mathrm{A} 42$ (0.1-3 $\mu \mathrm{M})$. KBH-A42 alone did not have any effect on the binding of NF-kB to DNA. In contrast, the DNA binding of another transcription factor AP-1 dose-dependently increased by $\mathrm{KBH}-\mathrm{A} 42$ in the LPS stimulated cells. In case of the cells without LPS stimulation, the increase in DNA binding of AP-1 was observed at $3 \mu \mathrm{M}$ of $\mathrm{KBH}-\mathrm{A} 42$. Next, the effect of KBH-A42 on the phosphorylation of MAP kinases (ERK1/2, SAPK/JNK, p38) was examined in the RAW 264.7 cell line using Western blotting method (Figure 5). KBH-A42 was pre-treated $1 \mathrm{~h}$ before LPS stimulation. The phosphorylation of p38, ERK1/2, and SAPK/JNK was examined at 10 min after LPS stimulation. The expression of p38 was not affected by the treatment of KBH-A42, but the phosphorylation of p38 was decreased with the increase of concentration of $\mathrm{KBH}-\mathrm{A} 42$. The phosphorylation of SAPK/JNK slightly decreased at 3 $\mu \mathrm{M}$ of $\mathrm{KBH}-\mathrm{A} 42$. The phosphorylation of ERK1/2 MAP kinase, however, showed no change with the increasing concentration of $\mathrm{KBH}-\mathrm{A} 42$.

\section{Docking study}

Docking study with a model of human HDAC-1 based on the crystal structure of a bacterial HDAC homologue (HDLP, PDB code 1C3R) showed that $\mathrm{KBH}-\mathrm{A} 42$ docked within the active site (Figure 6). The aliphatic chain between hydroxamate and $\delta$-lactam ring was bounded in the tubular hydrophobic pocket, and the hydroxamic acid moiety chelates to the catalytic $\mathrm{Zn}^{2+}$ ion bound in the active site. Although HDLP has a large deletion at entrance to the active site, the docking study suggests that $\mathrm{KBH}-\mathrm{A} 42$ binds in the active site of HDAC 1 by interacting the pharmacophoric groups with the corresponding amino acids in binding pocket.

\section{Discussion}

In the present study, we have demonstrated that the new HDAC inhibitor, $\mathrm{KBH}-\mathrm{A} 42$ had a promising anti-inflammatory activity by showing its abilities to 


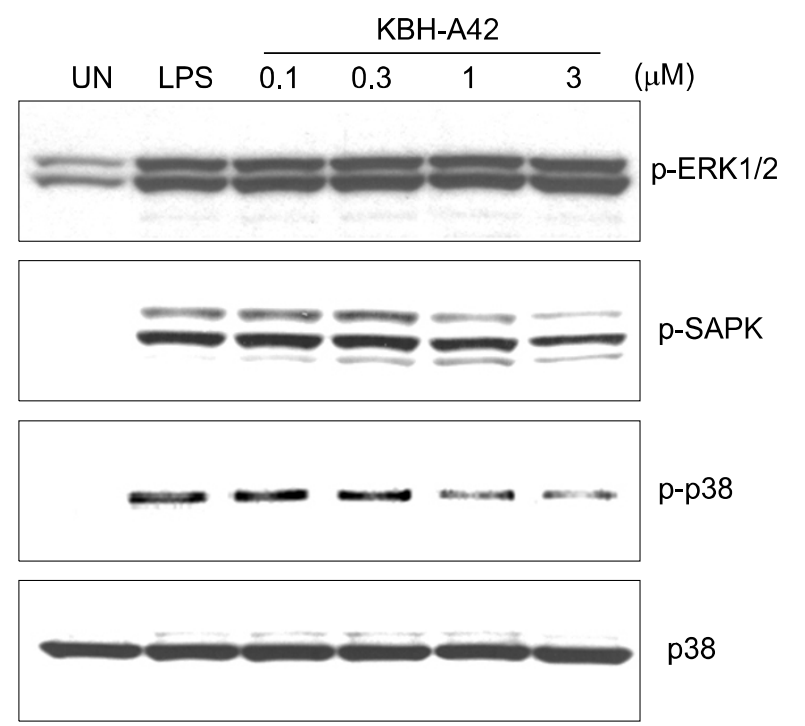

Figure 5. Western blotting for MAP kinases (phosphorylated ERK1/2, phosphorylated SAPK phosphorylated p38 and p38) at 10 min after LPS stimulation $(200 \mathrm{ng} / \mathrm{ml})$. HDAC inhibitor, KBH-A42 was treated $1 \mathrm{~h}$ before LPS stimulation.

reduce cellular TNF- $\alpha$ and NO production in RAW 264.7 cells and to inhibit TNF- $\alpha$ production in an in vivo mouse endotoxemia model. $\mathrm{KBH}-\mathrm{A} 42$ also inhibited NO production in LPS-induced peritoneal macrophages and did not affect cell viability in effective concentrations. The RT-PCR study on mRNA levels of TNF- $\alpha$, IL-1 $1 \beta$, IL- 6 , and iNOS proposed that the inhibition of these cytokines and NO might be resulted from the inhibition of mRNA expression. Thus, it appears that this inhibitor displayed in vitro and in vivo anti-inflammatory properties via suppression of a potent pro-inflammatory cytokine, TNF- $\alpha$, and a pro-inflammatory key mediator, NO. The EMSA study examined the effect of $\mathrm{KBH}-\mathrm{A} 42$ on binding to specific DNA sequences of NF- $\kappa B$ and $A P-1$. The binding of $N F-\kappa B$ to the DNA was not changed with increasing concentration of $\mathrm{KBH}-\mathrm{A} 42$ in the presence and absence of LPS stimulation, but DNA binding of another transcription factor AP-1, interestingly, dose-dependently increased with LPS stimulation. $\mathrm{KBH}-\mathrm{A} 42$ differentially regulated the phosphorylation of MAP kinases. While the phosphorylation of ERK1/2 and SAPK/JNK was not affected by $\mathrm{KBH}-\mathrm{A} 42$, the phosphorylation of p38 decreased with increasing the concentration of $\mathrm{KBH}-\mathrm{A} 42$.

HDAC inhibitors, SAHA and butyrate showed in vitro and in vivo anti-inflammatory activity profiles comparable to those of $\mathrm{KBH}-\mathrm{A} 42$. SAHA reduced serum levels of TNF- $\alpha$, IL-1 $\beta$, IL- 6 , and IFN- $\gamma$ in an in vivo LPS-induced endotoxemia animal model

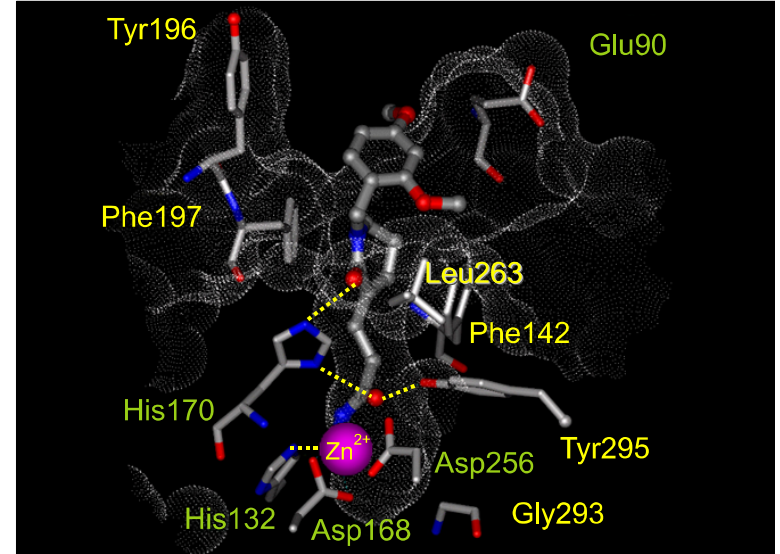

Figure 6 . The docked orientations for KBH-A42 bound to the HDAC1 catalytic core.

and also inhibited these cytokines in the LPSstimulated PBMC cell line (Leoni et al., 2002). Butyrate also inhibited the level of IL-12 in human monocytes (Saemann et al., 2000) and NO production in RAW 264.7 macrophage cells (Chakravortty et al., 2000). Although anti-inflammatory effects by these HDAC inhibitors are quite similar, the mechanisms involved in the regulation of $\mathrm{NF}-\kappa \mathrm{B}$ by these inhibitors are different in various types of cells. In LPS-stimulated monocytes and macrophages, butyrate inhibited NO production by stabilizing $I \kappa \mathrm{B}$, a natural $\mathrm{NF}-\kappa \mathrm{B}$ inhibitor, and inhibiting iNOS expression (Chakravortty et al., 2000). TSA and butyrate inhibited the proteosomal degradation of $I \kappa B, N F-\kappa B$ translocation and DNA binding in a colon cancer cell line. Meanwhile, TSA and SAHA enhanced the production of TNF- $\alpha$, IL-6 and NO by LPS stimulation in primary microglial cells (Yin et al., 2001). Taken together, the antiinflammatory effects and the mode of action of the various HDAC inhibitors vary with cell types and the classes of HDAC inhibitors. This variability may be caused by the presence of many kinds of tissue specific HDAC isoforms. Docking results of KBH-A42 with HDAC-1 homologous HDLP may suggest a possible molecular design to isoform selective HDAC inhibitors upon elucidation of the crystal structures of HDAC isoforms.

$\mathrm{KBH}-\mathrm{A} 42$ is a new class HDAC inhibitor. More understanding of the role of each HDAC isoform and mechanistic aspects of new classes of HDAC inhibitors could give more precise answers on these questions. Further study with new classes of HDAC inhibitors could be very valuable to understand the role of each HDAC isoforms. 


\section{Acknowledgments}

This work was supported by a grant from KRIBB Research Initiative Program, a grant (0405-NS01-0704-0001) of the Korean Health 21 R\&D Project, Ministry of Health and Welfare, and the Brain Korea 21 project, the Republic of Korea.

\section{References}

Archer SY, Meng S, Shei A, Hodin RA. p21(WAF1) is required for butyrate-mediated growth inhibition of colon cancer cells. Proc Natl Acad Sci USA 1998;95:6791-6

Archer SY, Hodin RA. Histone acetylation and cancer. Curr Opin Genet Dev 1999;9:171-4

Blanchard F, Chipoy C. Histone deacetylase inhibitors: new drug for the treatment of inflammatory diseases? Drug Discovery Today 2005;3:197-204

Chakravortty D, Koide N, Kato Y, Sugiyama T, Mu MM, Yoshida T, Yokochi T. The inhibitory action of butyrate on lipopolysccharide induced nitric oxide production in RAW 264.7 murine macrophage cells. J Endotoxin Res 2000;6: 243-7

D'Acuisto F, May MJ, Ghosh S. Inhibition of nuclear factor kappa (NF-кB): an emerging theme in anti-inflammatory therapies. Mol Interv 2002;2:22-35

Diakos C, Prieschl EE, Saemann M, Novotny V, Bohmig G, Csonga R, Baumruker T, Zlabinger GJ. Novel mode of interference with nuclear factor of activated T-cells regulation in T-cell by bacterial metabolite $\mathrm{n}$-butyrate. $\mathrm{J}$ Biol Chem 2002;277:24243-51

Gediya LK, Chopra P, Purushottamachar P, Maheshwari N, Najar VCO. A New Simple and High-Yield Synthesis of Suberoylanilide Hydroxamic Acid and Its Inhibitory Effect Alone or Combination with Retinoids on Proliferation of Human Prostate Cancer Cells. J Med Chem 2005;48: 5047-51

Jaenisch R, Bird A. Epigenetic regulation of gene expression: how the genome integrates intrinsic and environmental signals. Nat Genet 2003;33:245-54

Johnstone RW. Histone decetylase inhibitors: Novel drugs for the treatment of cancer. Nature Rev Drug Discovery 2002;1:287-99

Kim HM, Lee K, Park BW, Ryu DK, Kim K, Lee CW, Park S-K. Han JW, Lee HY, Han G. Synthesis, Enzymatic Inhibition and Cancer Cell Growth Inhibition of Novel $\delta$-Lactam-Based Histone Deacetylase (HDAC) Inhibitors. Bioorg Med Chem Lett 2006;16:4068-70

Kim HM, Ryu DK, Choi Y. Park BW, Lee K, Han SB, Lee CW, Kang MR, Kang JS, Boovanahalli SK, Park SK, Han JW, Chun TG, Lee HY, Nam KY, Choi EH, Han G. StructureActivity Relationship Studies of a Series of Novel $\delta$-Lactam based Histone Deacetylase Inhibitors J Med Chem 2007; 50:2737-41

Kouzarides T. Histone acetylase and deacetylase in cell proliferation. Curr Opin Genet Dev 1999;9:40-8

Kyung TW, Lee JE, Shin HH, Choi HS. Rutin inhibits osteoclast formation by decreasing reactive oxygen species

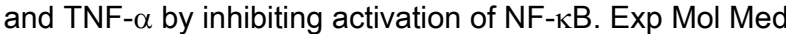
2008; $40: 52-8$

Leoni F, Zaliani A, Bertolini G, Porro G, Pagani P, Pozzi P, Dona G, Fossati G, Sozzani S, Azam T, Bufler P, Fantuzzi G, Goncharov I, Kim S-H, Pomerantz BJ, Reznikov LL, Siegmund B, Dinarello CA, Mascagni P. The antitumor histone deacetylase inhibitor suberoylanilide hydroxamic acid exhibits antiinflammatory properties via suppression of cytokines. Proc Natl Acad Sci USA 2002;99:2995-3000

Lipsky PE, van der Heijde DM, St. Clair W, Furst DE, Breedveld FC, Kalden JR, Smolen JS, Weisman M, Emery $P$, Feldmann M, Harriman GR, Maini RN. Infliximab and methotrexate in the treatment of rheumatoid arthritis. Anti-Tumor Necrosis Factor Trial in Rheumatoid Arthritis with Concomitant Therapy Study Group. N Engl J Med 2000;343: 1594-602

McMartin C, Bohacek RS. QXP: Powerful, rapid computer algorithms for structure-based drug design. J Comput Aided Mol Des 1997;11:333-44

Moreland LW, Baumgartner SW, Schiff MH, Tindall EA, Fleischmann RM, Weaver AL, Ettlinger RE, Cohen S, Koopman WJ, Mohler K, Widmer MB, Blosch CM. Treatment of rheumatoid arthritis with a recombinant human tumor necrosis factor receptor (p75)-Fc fusion protein. N Engl J Med 1997;337:141-7

Newton RC, Decicco CP. Therapeutic potential and strategies for inhibiting tumor necrosis factor- $\alpha$. J Med Chem 1999;42:2295-314

Palladino MA, Bahjat FR, Theodorakis EA, Moldawer LL. Anti-TNF- $\alpha$ therapies: the next generation. Nature Rev Drug Discovery 2003;2:736-46

Saemann MD, Bohmig GA, Osterreicher $\mathrm{CH}$, Burtscher $\mathrm{H}$, Parolini O, Diakos C, Stockl J, Walter H, Horl WH, Zlabinger GJ. Anti-inflammatory effects of sodium butyrate on human monocytes: potent inhibition of IL-12 and up-regulation of IL-10 production. FASEB J 2000;14:2380-2

Wu J, Grunstein M. 25 years after the nucleosome model: chromatin modifications. Trends Biochem Sci 2000;25: 619-3

Yi T, Baek J-H, Kim H-J, Choi M-H, Seo S-B, Ryoo H-M, Kim G-S, Woo KM. Trichostatin A-mediated upregulation of p21 ${ }^{\text {WAF1 }}$ contributes to osteoclast apoptosis. Exp Mol Med 2007;39:213-21

Yin L, Laevsky G, Giardina C. Butyrate suppression of colonocyte NF- $\kappa \mathrm{B}$ activation and cellular proteosome activation. J Biol Chem 2001;276:44641-6 